\title{
Modification to a process of making skewers in a company that produces meat products
}

\section{Modificación a un proceso de elaboración de brochetas en una empresa productora de derivados de la carne}

\author{
CANO-CARRASCO, Adolfo †*, FORNÉS-RIVERA, René Daniel, CONANT-PABLOS, Marco \\ Antonio and RODRÍGUEZ-MUÑIZ, Miroslava Teresa
}

\section{Instituto Tecnológico de Sonora}

ID $1^{\text {st }}$ Author: Adolfo Cano-Carrasco / ORC ID: 0000-0002-3392-3667, Researcher ID Thomson: G-5035-2018, arXiv Author ID: adolfo.cano, CVU CONACYT ID: 266064

ID $1^{\text {st }}$ Coauthor: René Daniel, Fornés-Rivera / ORC ID: 0000-0002-7438-0056, Researcher ID Thomson: G-3906-2018, arXiv Author ID: rene_fornes, CVU CONACYT ID: 280435

ID $2^{\text {nd }}$ Coauthor: Marco Antonio, Conant-Pablos / ORC ID: 0000-0002-3364-3702, Researcher ID Thomson: G-39112018, arXiv Author ID: MConant, CVU CONACYT ID: 687331

ID $3^{\text {rd }}$ Coauthor: Miroslava Teresa, Rodríguez-Muñiz / ORC ID: 0000-0001-6825-9367

DOI: $10.35429 / J E S .2019 .5 .3 .18 .24$

Received July 15, 2019; Accepted October 28, 2019

\begin{abstract}
This research analyzes a skewer production line of a meat processing company due to the fact that it presents bottlenecks and leisure time, with the objective of proposing improvements in the method through the analysis of operations. The procedure was to know the specifications of the product and the process, study the activities and determine standard times by the Maytag Company method. The results show that the critical operations are those of portioning and assembling the product for which three improvement proposals were designed whose evaluation determined that the mold method is the most suitable for the production of skewers. The chosen method is considered more efficient, since when compared to the current method, it presents a decrease in the operating time of $11.68 \mathrm{~s}$ per product, as well as $7.88 \mathrm{~s}$ in leisure time, resulting in an increase in production of $321.95 \mathrm{~kg}$ per shift, this represents an increase of $124.83 \%$ in the efficiency of the production line, making evident the relevance of these techniques for the continuous improvement of the processes.
\end{abstract}

\begin{abstract}
Resumen
Esta investigación analiza una línea de producción de brochetas de una empresa procesadora de carne debido a que esta presenta cuellos de botella y tiempo de ocio, teniendo por objetivo proponer mejoras en el método mediante el análisis de las operaciones. El procedimiento fue conocer las especificaciones del producto y el proceso, estudiar las actividades y determinar tiempos estándares por el método Maytag Company. Los resultados muestran que las operaciones críticas son las de porcionar y ensamblar el producto para las cuales se diseñaron tres propuestas de mejora cuya evaluación determinó que el método con molde es el más adecuado para la producción de brochetas. El método elegido se considera más eficiente, ya que al compararlo con el método actual, presenta una disminución en el tiempo de operación de $11.68 \mathrm{~s}$ por producto, así como $7.88 \mathrm{~s}$ en tiempo de ocio, resultando esto en un incremento de la producción en $321.95 \mathrm{~kg}$ por turno, esto representa un aumento del $124.83 \%$ en la eficiencia de la línea de producción, haciendo evidente la relevancia de estas técnicas para el mejoramiento continuo de los procesos.
\end{abstract}

Acciones, Mejora, Eficiencia

\footnotetext{
$\dagger$ Researcher contributing as first author.
} 


\section{Introduction}

The production of meat in Mexico is the result of the contribution of all its states in greater or lesser quantity, however there are States that excel in the national production of meat such as Veracruz and Jalisco in beef and chicken, as well as the case of Jalisco and Sonora who are leaders in pork (Haro, 2019).

The market in which this type of industry develops requires a high range of products, as an example there are different types of cuts and others ranging from portioned pork dishes to ready-to-eat dishes, where a wide variety of combinations is included, there are more than sixty product presentations that are made in some of the producing companies implying having an area or department (in most cases it is small) of new product development involving a high use of installed capacity (Taddei y Preciado, 2008). Nowadays companies face the need to adapt to a dynamic and unpredictable environment, product of constant local and global change, which is why their actions are aimed at achieving higher levels of quality, so they frequently work to improve products and processes to ensure customer satisfaction and thus be competitive (Yánez y Yánez, 2012).

From the point of view of the food processing industry, the link with customers is only possible through retailers that control and regulate the market. Most food and beverage manufacturers have to do business with powerful retailers, which demand a wide range of products, shorter and more frequent delivery times, and price reductions. For any sector in the food processing industry, cost is a major driving force. Low-cost leadership is the "predominant" business strategy in the food processing industry (Rakesh \& Om Prakash, 2006).

The mechanism under which Mexican producers export to more than 60 countries around the world is the TIF (Federal Inspection Type) system, which ensures that the processes carried out there comply with strict health standards, resulting in products with exportation quality.

As of this year 2018, pork can be exported to the US, since the American country has determined that Mexican pork is free of traditional swine fever.
Considerations of the possible new NAFTA (North American Free Trade Agreement) agreement have caused Mexico to seek new export destinations for all types of meat it produces (Rioja-Scott, 2018). According to a market study prepared by ICEX Spain, Mexico ranks as third exporter, with a growth of 49.77\% since 2014 (ICEX, 2019).

The above raises an area of opportunity for the productive sector allowing the increase in the use of the resources that constitute its installed production capacity implying the need to innovate and improve the processes of meat production and thus remain in the international market.

\section{Problem}

The company under study consists of a trace of this nature TIF. The main products of this company are destined for the Asian market, being its most important client the Japanese market and the most demanded product is pork. The swine meat market in Japan is especially relevant. According to FAO statistics, this country is the second largest importer of pork meat only behind China, and the fifth in pork sausages. In addition, pork is the second most imported agricultural and livestock product in Japan, after corn (ICEX,2019).

Part of the operational processes of this organization are carried out in the portioning area, where the research work will be carried out, in this part value is added to the product with operations that detail the raw material consisting of parts of the pig such as the loin , ham, jowl and bacon, are processed by specific cuts to obtain products such as chop loin, belly kushi (skewers), jowl kushi, which must meet specific characteristics of size, color, shape and weight, to meet specifications of customers.

Part of the operational processes of this organization are carried out in the portioning area, where the research work will be carried out, in this part value is added to the product with operations that detail the raw material consisting of parts of the pig such as the loin, ham, jowl and bacon, are processed by specific cuts to obtain products such as chop loin, belly kushi (skewers), jowl kushi, which must meet specific characteristics of size, color, shape and weight, to meet specifications of customers 


\section{Objective}

Propose improvements in the method of making skewers by analyzing operations to make it more efficient.

\section{Theoretical framework}

A culture of continuous improvement is directly related to the typical patterns of behavior with which organizations cope with their activities. The company's values rest on a set of guidelines. A value is something in which the organization and its people believe, therefore it determines the way in which people behave. Some evidence of these values is the training provided for all, aimed at the elimination of errors and waste, the construction of continuous improvement teams, involvement from above to lower levels in decision making, preparing the worker for innovation, communicating and to try new ideas.

These values are put into practice on a day-to-day basis by sharing ideas among team members, weekly reports of developed topics, problems and successes, regular teamwork sessions, celebration of individual and team achievements. (Institute of Management Services, 2008).

An important fact published by Lucey (2008) states that the level of adoption of Lean practices in the United Kingdom varies depending on the sector, so the engineering sector shows 34\%, Electronics $14 \%$, Pharmaceutical 8\%, Telecommunications $7 \%$ and the food and beverage sector with $6 \%$. Which shows that the highest level of concentration lies in the engineering sector and the lowest in the food and beverage sector. (Bhasin, 2015).

Some authors (such as Lucey 2005; Manos 2007; Proudlove et al. 2008) cited by Machado \& Crespo (2012) suggest that the medium and long term results in the implementation of Lean and Six sigma are due to a standardized training, commitment of employees with the company and the client, monitoring of results, commitment and responsibility of management to maintain and improve profits and also learn from external support on how to develop internal mechanisms for continuous improvement.
There are many resources that are invested in improving processes, among which we can mention the purchase of machinery, training, and efforts to reach quality standards, however they devote little money to the development of technology.

The main purpose of many companies is to develop new processes and products or the continuous improvement of these (Domínguez, 2006).

One of the survival strategies of companies competing in a sector is to develop innovative approaches to reduce the costs they face in their processes. One of the main approaches that production companies apply to gain competitive advantage is process innovation (Felekoglu \& OzmehmetTasan, 2019).

Reduce the cost per transaction and production, more competitive and better quality products, advantages in the development of relations between producer and buyer as well as, an improvement in relations with customers and suppliers are examples of what process innovation can provide (Reguia 2014).

Process innovation is the implementation / adoption of new or significantly improved production or delivery methods that may involve changes in equipment, human resources, work methods or a combination of these (OECD 2005, p. 9).

Production processes consist of valueadded activities, non-value-added activities and non-value-added activities necessary for the operation, in which the value is defined by the customer's requirements. (Womack \& Jones, 1996).

Slender manufacturing (lean production) has in general terms the intention of making production processes efficient through cost reduction, reliable deliveries, low cycle times based on different methods and techniques such as Kaizen, 5s, Poka Yoke, Work Standardized, Teamwork, Total productive maintenance, Failure Mode Analysis, among others.

The first contributions were thanks to the work of Ohno, Womack and Jones in the 90's (Neumann, Kohlhuber \& Hanusch, 2012). 


\section{Methodology}

An applied research was carried out in the portioning area (added value), specifically in the operations of the belly kushi 30 gr. Processing line, in which 14 operators participate. The following resources were used to carry out this investigation: (1) Format for time study. Work analysis questionnaires. (2) Qualification table of the Westinghouse System. (3) Work sampling methodology. (4) T student table. (4) Formulas for calculating the standard operating time and line balancing. (5) Digital camera. (6) Stopwatch. (9) Tools for product development. Short knife, scale, plastic sheets, belly marking mold, protective gloves and vernier.

The methodology is an adaptation of Freivalds and Niebel (2014). The steps taken consisted of: (1) Identification of activities and relevant information of the belly kushi making process 30 gr. (2) Use of questionnaires to evaluate the operations and analyze the work, (3) Classification of the activities in elements and qualification of the operator's performance. Tolerances were established based on the table of supplements and tolerances, these tolerances were used for the determination of the standard time. (4) Analysis of operations and study of times to detect activities of No added value, unnecessary or that should be improved. (5) Preparation of proposals using flowcharts to describe operations. (6) Each proposal was executed in a pilot way identifying its advantages and disadvantages. (7) Selection of the proposal using productivity criteria. (8) Detailed documentation of the procedure according to characteristics in raw material and product. (9) Pilot test of the improvement proposal, to obtain standard time and compare the proposal with the current method. (10) Balancing the line of the new method.

\section{Results}

Three improvement proposals were designed and the mold method was found to be the most suitable for the production of skewers (see annex 2 for photos related to the new process).

To make the new method efficient, the line was balanced, the parameters considered were those shown in Table 1.

\begin{tabular}{|l|r|}
\hline Line Balancing Results \\
\hline Line operations time: & 19.49 \\
\hline Skewers to produce: & 19500 \\
\hline Kilograms to produce: & 585 \\
\hline Operators Required: & 14 \\
\hline Units per hour: & 2437.5 \\
\hline Estimated Time Allocated x Station: & 1.47692308 \\
\hline Skewers per second: & 0.6771 \\
\hline
\end{tabular}

Table 1 Parameters considered for balancing operations

For the implementation of this method, the work line would be distributed in 3 stations $\mathrm{A}, \mathrm{B}$ and $\mathrm{C}$ as shown in table 2 , the number of operators required would be 14 as shown in table 2.

\begin{tabular}{|c|c|c|c|c|c|c|}
\hline & Operación & $\begin{array}{l}\text { Tiemp } \\
\text { o Est }\end{array}$ & $\begin{array}{l}\text { Tiemp } \\
\text { o Asig. }\end{array}$ & $\begin{array}{l}\text { Op. } \\
\text { Teórico }\end{array}$ & $\begin{array}{l}\text { No. } \\
\text { Op }\end{array}$ & Cap(u) \\
\hline \multirow{5}{*}{ 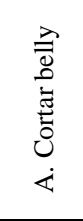 } & Tomar Belly & 0.36 & 0.36 & 0.270833 & 1 & 24,202 \\
\hline & Marcar Belly & 0.46 & 0.46 & 0.346064 & & \\
\hline & Cuadrar Belly & 0.22 & 0.22 & 0.165509 & & \\
\hline & $\begin{array}{l}\text { Cortar Tiras de } \\
\text { Belly. }\end{array}$ & 0.15 & 0.15 & 0.112847 & & \\
\hline & Tiempo total & 1.19 & 1.19 & 0.895254 & & \\
\hline \multirow{2}{*}{ 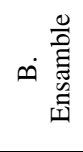 } & $\begin{array}{l}\text { Ensamblar } \\
\text { Brocheta }\end{array}$ & 13.41 & 1.49 & 10.08854 & 9 & 19,329 \\
\hline & Tiempo total & 13.41 & & 9.6 & & \\
\hline \multirow{4}{*}{ 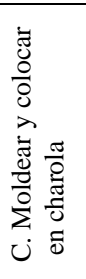 } & $\begin{array}{l}\text { Tomar } \\
\text { Brochetas y } \\
\text { Moldear }\end{array}$ & 3.27 & 0.817 & 2.460069 & & \\
\hline & $\begin{array}{l}\text { Colocar } \\
\text { plástico. }\end{array}$ & 0.46 & 0.115 & 0.346064 & 4 & 23558 \\
\hline & $\begin{array}{l}\text { Acomodar } \\
\text { brocheta }\end{array}$ & 1.16 & 0.29 & 0.872685 & & \\
\hline & Tiempo total & 4.89 & 1.222 & 3.678819 & & \\
\hline
\end{tabular}

Table 2 Balance of operations analysis

With this configuration the balancing efficiency results in $87 \%$ see equation (1).

Eficiencia $=\frac{\Sigma \text { tiempo est. }}{\text { no estaciones } * \text { tiempo asignado }}=\frac{(1.19+1.49+1.22) \mathrm{seg}}{3 * 1.49 \mathrm{seg}}=87 \%$

The data presented in Table 3 compare the production between the current and the proposed method.

\begin{tabular}{|l|r|l|r|}
\hline Método Actual & $\begin{array}{l}\text { Tiempo } \\
\text { Estándar }\end{array}$ & Método Propuesto & $\begin{array}{l}\text { Tiempo } \\
\text { Estándar }\end{array}$ \\
\hline $\begin{array}{l}\text { Tomar y acomodar } \\
\text { piezas de belly }\end{array}$ & 0.49 & $\begin{array}{l}\text { Tomar y acomodar } \\
\text { piezas de belly }\end{array}$ & 0.36 \\
\hline Corta cuadros Belly & 0.96 & Marcar piezas belly. & 0.46 \\
\hline Porcionar. & 9.87 & Cuadrar belly & 0.22 \\
\hline Ensamblar brocheta & 13.41 & Cortar tiras de belly. & 0.15 \\
\hline Verificar peso & 1.55 & Ensamblar brocheta. & 13.41 \\
\hline Moldear. & 3.27 & Moldear. & 3.27 \\
\hline $\begin{array}{l}\text { Colocar plástico en } \\
\text { charola }\end{array}$ & 0.45 & $\begin{array}{l}\text { Colocar plástico en } \\
\text { charola. }\end{array}$ & 0.45 \\
\hline $\begin{array}{l}\text { Colocar brocheta en } \\
\text { charola. }\end{array}$ & 1.16 & $\begin{array}{l}\text { Colocar brocheta en } \\
\text { charola. }\end{array}$ & 1.16 \\
\hline Tiempo de ocio & 9.27 & & 1.01 \\
\hline \multicolumn{2}{|l|}{} \\
\hline
\end{tabular}

Tabla 3 Comparación de métodos

CANO-CARRASCO, Adolfo, FORNÉS-RIVERA, René Daniel, CONANT-PABLOS, Marco Antonio and RODRÍGUEZ-MUÑIZ, Miroslava Teresa. Modification to a process of making skewers in a company that produces meat products. Journal-Economic Systems. 2019 
Finally, the production run complied with the specifications by $95 \%$, as a summary see table 4 the current method allows a decrease of the operating time of $11.68 \mathrm{sec} / \mathrm{u}$, in the same way the leisure time decreases $8.7 \mathrm{sec}$ the time of leisure.

Another aspect that is considered important is that at the time the proposal is implemented an increase in production of 321.95 kilograms is expected, this represents an increase in the efficiency of the line of $124.83 \%$.

\begin{tabular}{|l|r|r|r|}
\hline \multicolumn{1}{|c|}{$\begin{array}{c}\text { Método } \\
\text { actual }\end{array}$} & Diferencia & \multicolumn{1}{c|}{$\begin{array}{c}\text { Método } \\
\text { prop }\end{array}$} \\
\hline Brochetas cant. & 8597 & 10731.85 & 19329 \\
\hline Kilogramos & 257.91 & 321.95 & 579.86 \\
\hline Tiempo por brocheta & 31.16 & 11.68 & 19.48 \\
\hline Tiempo de ocio (seg.) & 9.27 & 8.703 & 0.5675 \\
\hline
\end{tabular}

Tabla 4 Resumen del análisis comparativo

From table 4 the production deficit of (19500-19329) is 171 skewers that will require a time of $171 * 13.41 \mathrm{sec}$ which is equivalent to 38.2 minutes of time that can be sustained with the help of a station 3 operator. The recommendation is to use it for one hour increasing the capacity to 19600 skewers and the capacity of the station 3 drops to 22820 which does not affect the planned standard of 19500 skewers.

Even though the work template is the same as in the previous method, the new process executes the operation more efficiently and allows to reach a higher level of product quality.

\section{Conclusions}

The application of work study techniques is useful for any productive system as evidenced in the results of this project, in which the use of work study techniques contributed to the continuous improvement of the process. In this case, an increase of 321.95 kilograms is projected, which represents a $124.83 \%$ increase in efficiency, which will make it possible to reach and even exceed current demand.

Although the improvements presented are simple, the impact they produce is significant. One factor that prevented the implementation of the proposal was the potential delay in the delivery of products to the customer, so managers said that training staff for the implementation of the new method could cause an increase in the delivery time of orders.
It is considered that the present research work can be adapted to other products such as the skewers of 50gr and $100 \mathrm{gr}$ and in this way increase the productivity in the production line of these products.

\section{References}

Bhasin, S. (2015). Lean Management Beyond Manufacturing, Springer International Publishing Switzerland.

Domínguez, D. J. (2006). Optimización simultánea para la mejora continua y reducción de costos en procesos Ingeniería y Ciencia, vol. 2, núm. 4, septiembre, 2006, pp. 145-162 Universidad EAFIT Medellín, Colombia.

Felekoglu, B. \& Ozmehmet T. S. (2019). Investigating the Impact of Process Innovation Over Profitability and Productivity: A Food Sector Application. Springer International Publishing AG, part of Springer Nature, J. Mula et al. (eds.), New Global Perspectives on Industrial Engineering and Management, Lecture Notes in Management and Industrial Engineering.

Freivalds, A. y Niebel, B. W. (2014). Ingeniería industrial: métodos, estándares y diseño del trabajo. McGraw-Hill Interamericana.

Haro, L. F. (2019). Importancia de la industria cárnica en México. Director General del Consejo Nacional Agropecuario. INFORURAL.

ICEX (2019). El mercado del porcino en Japón. Oficina Económica y Comercial de la Embajada de España en Tokio. ICEX España Exportaciones e inversiones E.P.E., M.P.. Estudios de mercado. Los datos de este estudio han sido actualizados por Marta Calleja Escudero Bajo la supervisión de la Oficina Económica y Comercial de la Embajada de España en Tokio.

Institute of Management Services (2008). Continuity Is The Key 26 A case study explaining how Kaizen brought continuous improvement to Leyland Trucks. Journal of the Institute of Management Services. The Sustainability of he Sustainability of Lean Transformation. Manufacturing and Lean manufacturing in the UK. With permission of Thetimes100.co.uk, Vol. 52-3. 
Lucey, J. (2008). The state of lean manufacturing in the UK. Management Services Autumn, 16-26.

Machado, G. C. \& Crespo de C., J. (2012). Lean, a Tool Set or a Mind Set? A healthcare Case Study. En Walters D., Herbert J., Olhager J., Schonberger R. J. Modelling Value: Selected Papers of the 1st International Conference on Value Chain Management. Contributions to Management Science. Physica-Verlag Heidelberg.

Manos, A. (2007). The benefits of Kaizen and Kaizen events. Quality Progress, 40(2), 47-48. Neumann, C., Kohlhuber, S. \& Hanusch S. (2012). Lean Production in Austrian Industrial Companies: An Empirical Investigation. Department of Industrial Management, University of Applied Sciences JOANNEUM, Karpfenberg, Austria in H. Jodlbauer et al. (eds.), Modelling Value, Contributions to Management Science, Springer-Verlag Berlin Heidelberg.

OECD (2005). The measurement of scientific and technological activities: Guidelines for collecting and interpreting innovation data: Oslo manual (3rd ed.). Paris: OECD.

Proudlove, N., Moxham, C. \& Boaden, R. (2008). Lessons for Lean in healthcare from using six sigma in the NHS. Public Money and Management, 28(1), 27-34.

Rakesh, J. \& Om, P. (2006). "Driving improvement opportunities in the food processing industry through benchmarking". Int. J. Process Management and Benchmarking, Vol. 1, No. 4.

Reguia, C. (2014). Product innovation and the competitive advantage. European Scientific Journal, ESJ, 10(10), 140-157.

Rioja-Scott, I. (2018). Informe anual de México 2018. INDUSTRIA ALIMENTARIA.

Taddei, C. y Preciado, M. (2008). Comportamiento estratégico en la industria alimentaria Plantas del noroeste de México. Economía mexicana NUEVA ÉPOCA, vol. XVII, núm. 2.

Yánez, J. y Yánez, R. (2012). Auditorías, Mejora Continua y Normas ISO: factores clave para la evolución de las organizaciones. Ingeniería Industrial. Actualidad y Nuevas Tendencias [en linea] 2012, III (JulioDiciembre).

\section{Annexes}

Annex 1 Product Spec Sheet

\begin{tabular}{|c|c|c|}
\hline \multicolumn{3}{|c|}{$\begin{array}{l}\text { Product name: Belly Kushi } 30 \mathrm{gr} \text {. } \\
\text { Physical presentation of the product }\end{array}$} \\
\hline \multirow{6}{*}{$\begin{array}{l}\text { Skewer } \\
\text { presentation }\end{array}$} & Features & Specification \\
\hline & Raw material & Belly (Bacon). \\
\hline & Smell & Not acidic, not rancid. \\
\hline & Weight & $29-32$ gr. piece \\
\hline & \multirow[t]{3}{*}{ Dimensions } & Lenght: $9 \mathrm{~cm}$. skewer. \\
\hline & & Width $3.5 \mathrm{~cm}$. \\
\hline \multirow{4}{*}{ 트르를 } & & Thickness: $0.9 \mathrm{~cm}$. \\
\hline & Amount of fat & $\begin{array}{l}\text { Maximum } 50 \% \text { of the } \\
\text { total content of the piece. }\end{array}$ \\
\hline & Foreign materials & Absent \\
\hline & Harmful fauna & Absent \\
\hline \multirow[b]{3}{*}{$\begin{array}{l}\text { Raw Material } \\
\text { Presentation }\end{array}$} & Temperature & Frozen $-15^{\circ} \mathrm{C}$. \\
\hline & \multicolumn{2}{|l|}{ Packing. } \\
\hline & \multicolumn{2}{|c|}{$\begin{array}{l}60 \text { pieces will be packed in a } 38 \times 18 \times 8.5 \mathrm{~cm} \\
\text { box, inside the box a } 48 \times 50 \mathrm{~cm} \text { blue plastic } \\
\text { sheet is placed, then } 6 \text { layers with } 9 \text { pieces and } \\
\text { a } 6 \text { pieces layer are placed . } 6 \text { boxes with these } \\
\text { specifications are made. Subsequently the } 6 \\
\text { boxes are placed in a box with dimensions } 38 \\
x 41 \times 28.5 \mathrm{~cm} \text {. }\end{array}$} \\
\hline roms & \multicolumn{2}{|c|}{ Description. } \\
\hline $\begin{array}{l}\text { Pieces with } \\
50 \% \text { of fat. }\end{array}$ & \multicolumn{2}{|c|}{$\begin{array}{l}\text { Skewer of rectangular shape of individual } \\
\text { cuts, only } 4 \text { pieces are assembled on the } \\
\text { wooden stick of } 15 \mathrm{~cm} \text {. long which should not } \\
\text { exceed the top of the product at the time of } \\
\text { assembly, nor should it be visible on the } \\
\text { surface of the product. At the time of } \\
\text { assembly the piece must have meat on the top } \\
\text { and fat on the bottom. }\end{array}$} \\
\hline
\end{tabular}

Annex 2 Photos of activities in the proposed process

Marking mold

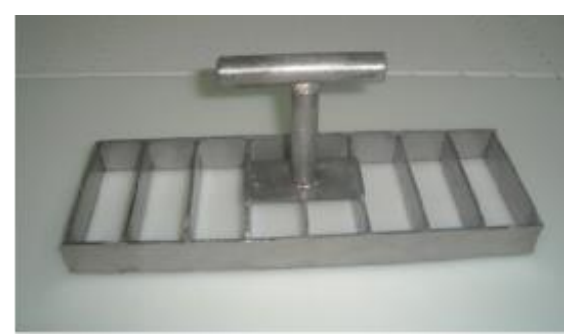

Marked framing of Belly with mold

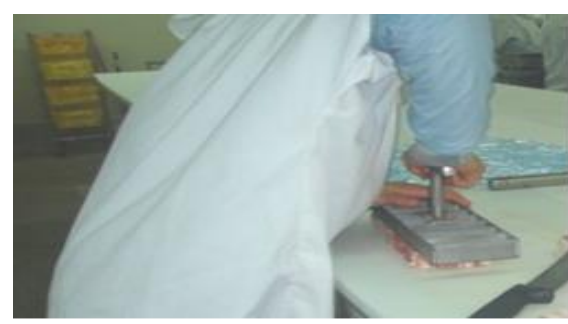

CANO-CARRASCO, Adolfo, FORNÉS-RIVERA, René Daniel, CONANT-PABLOS, Marco Antonio and RODRÍGUEZ-MUÑIZ Miroslava Teresa. Modification to a process of making skewers in a company that produces meat products. Journal-Economic Systems. 2019 
Framing belly with mold.

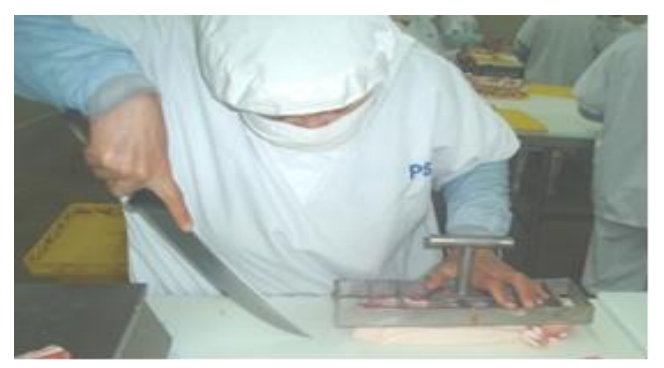

Belly cut marked.

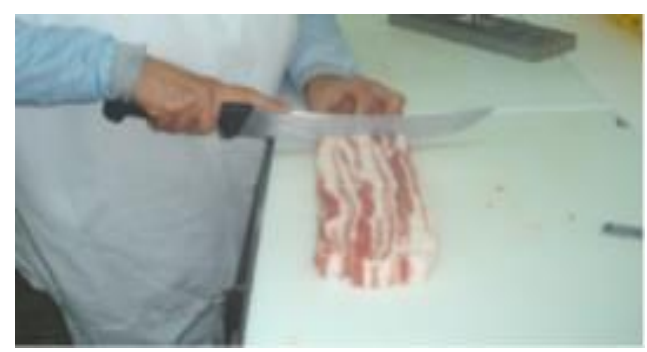

Measurement of dimensions

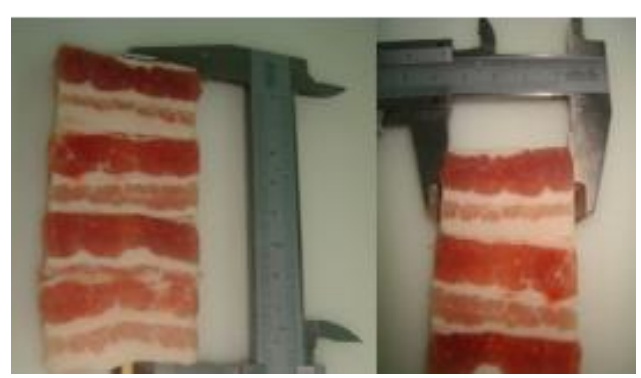

Comfort in mold for insertion. Which was discarded for producing defect in the stick. The use of a pressure change cap is recommended.

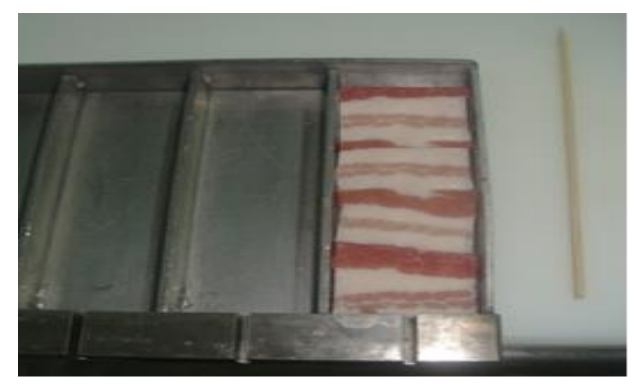

Packed in trays

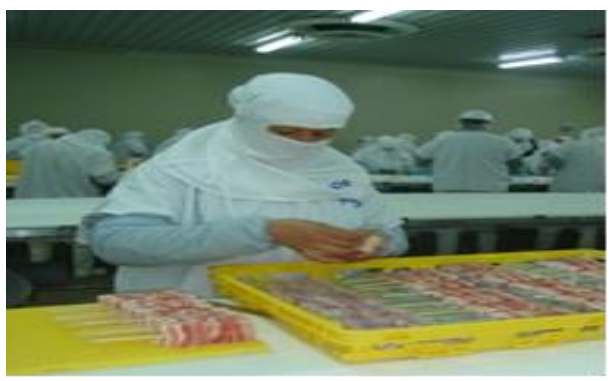

